\title{
Refinement of Alternate Wetting and Drying Irrigation Method for Rice Cultivation
}

\begin{abstract}
Experiments were conducted at BRRI farm Gazipur during Boro season 2010-12 to determine maximum depth of water level below ground surface in alternate wetting and drying (AWD) method. The experiment was laid out in a randomized complete block design with four irrigation treatments. The treatments of AWD method were: $T_{1}=$ continuous standing water, $T_{2}=$ irrigation when water level reached $15 \mathrm{~cm}$ below ground level, $\mathrm{T}_{3}=$ irrigation when water level reached $20 \mathrm{~cm}$ below ground level and $\mathrm{T}_{4}=$ irrigation when water level reached $50 \mathrm{~cm}$ below ground level. The experiment involved BRRI dhan 28 as a test crop. The treatment $T_{2}$ gave the highest grain yield (5.9 and 6.2 ton/ha) in 2010-11 and 2011-12, respectively. Maximum benefits per hectare were found Tk. 5476 and 4931 for using 807 and $880 \mathrm{~mm}$ water during 2010-11 and 2011-12 respectively and thus water productivity was $7.1 \mathrm{~kg} /$ ha-mm in $T_{2}$ for both the seasons. Continuous standing $\left(T_{1}\right)$ water (1013 and $1100 \mathrm{~mm}$ ) gave comparable grain yield 5.7 and 6.0 ton/ha in 2010-11 and 2011-12, respectively. Minimum water productivity was found in treatment $\mathrm{T}_{1}(5.6$ and $5.4 \mathrm{~kg} / \mathrm{ha}-\mathrm{mm})$ for both the seasons. Application of irrigation when water was $15 \mathrm{~cm}$ below soil surface was found most profitable in AWD system and the grain yield was decreased when water level was below $15 \mathrm{~cm}$ depth. Therefore, the recommended AWD technology could increase rice yield and save irrigation water by 25-30 percent.
\end{abstract}

Priya Lal Chandra Paul¹, M.A. Rashid ${ }^{2}$ Mousumi Paul ${ }^{3}$

Key words: Alternate wetting and drying irrigation, Boro rice, Yield, Water productivity

\section{INTRODUCTION}

The availability of freshwater for agriculture is declining in many Asian countries including Bangladesh (Postal, 1997), while the demand for rice is increasing in Asia (Pingali et al., 1997). Water should be utilized properly for optimum and economic yield. Tuong and Bouman (2003) estimated that by 2025, 15-20 million ha of irrigated rice will suffer varying degree of water scarcity. However, there is a possibility that rice yield could be increased by improved soil-water management. According to the recent estimates, out of 8.4 Mha of cultivable land, about 5.0 Mha arable lands have been brought under irrigation (MOA, Bangladesh 2010). It implies that about $60 \%$ of total cultivable lands are irrigated. Both surface and groundwater are used for irrigation purpose. At present more than $70 \%$ of the irrigated area is served with groundwater and less than 30\% with surface water (BBS, 2009).

Traditionally, lowland rice is cultivated in flooded fields. According to global average, 3400 liters of water are used to grow one kilogram of rice (Hoekstra, 2008), which makes rice a very water-intensive crop. It has been proven that irrigated rice does not necessarily require this amount of water. There is scope for water-saving in rice irrigation based on evapotranspired water (1,432 L) to produce $1 \mathrm{~kg}$ of rough rice (IRRI, 2010). The actual amount of water, used by the farmers for land preparation and during crop growth period is much higher than actual field requirement. Paddy farmers often store water in their fields as a back-up safety measure against uncertainty in water supply. Also, there is often field to field irrigation. This leads to a high amount of surface runoff, seepage and percolation

\footnotetext{
${ }^{1}$ Scientific Officer, Irrigation and Water Management Division, Bangladesh Rice Research Institute, Gazipur 1701.

${ }^{2}$ Chief Scientific Officer, Irrigation and Water Management Division, Bangladesh Rice Research Institute, Gazipur 1701.

${ }^{3}$ Extension Oficer, Department of Agricultural Extension, Bangladesh
} 
accounting for about 50-80 percent of the total water input to the field (Sharma, 1989). One method to save water in irrigated rice cultivation is the intermittent drying of the fields instead of keeping them continuously flooded. This method is referred to as alternate wetting and drying (AWD) method. By applying AWD, farmers or pump-owners can save 15 to $30 \%$ irrigation water.

Water productivity, i.e. amount of rice produced with a certain volume of irrigation water increases compared to conventional cultivation (Bouman et al., 2007). Savings in energy and fuel consumption represent another significant advantage of AWD. Consequently, AWD has potential to reduce input cost for water, irrigation services, as well as energy and fuel. The AWD is a mature technology that has been widely adopted in China, Vietnam and Indonesia ( $\mathrm{Li}$ and Barker 2004). It is also a recommended practice in northwest India and is being tested by farmers in the Philippines (Bouman et al., 2007). The AWD practice improved rooting system, reduced lodging (because of a better root system), periodic soil aeration and better control of some diseases (Bouman et al., 2007). In this contest the experiment was undertaken with extensive monitoring and determined the profitability of AWD method through saving irrigation water, fuel and energy. The objectives of the study were (i) to determine optimum depth of water level below ground surface in rice field after disappearing of standing water (ii) to determine amount of saving water with satisfactory grain yield (iii) to determine economic viability of AWD method for Boro rice cultivation.

\section{MATERIALS AND METHODS}

The experiment was conducted at BRRI research farm, Gazipur during Boro season 2010-12. Soil type was clay loam. Four irrigation treatments were used and each replicated thrice. The treatments were: $T_{1}=$ Continuous standing water, $T_{2}=$ Irrigation $(5-7 \mathrm{~cm})$ when water was $15 \mathrm{~cm}$ below the soil surface, $T_{3}=$ Irrigation $(5-7 \mathrm{~cm})$ when water was $20 \mathrm{~cm}$ below the soil surface and $\mathrm{T}_{4}=$ Irrigation $(5-7 \mathrm{~cm})$ when water was $50 \mathrm{~cm}$ below the soil surface. Unit plot size was $11 \mathrm{~m} \times 6 \mathrm{~m}$. Each plot was separated by $1 \mathrm{~m}$ of buffer zone, while each of the replications was demarcated by a buffer zone of $1.5 \mathrm{~m}$. Seedlings were raised outside the experimental field and 40-day old seedlings were transplanted at $20 \times 15 \mathrm{~cm}$ spacing. BRRI recommended (Adunik dhaner chash) cultural and fertilizer management practices were followed in growing rice. The whole amount of $\mathrm{P}, \mathrm{K}, \mathrm{Zn}$ and $\mathrm{S}$ were applied as basal at the final land preparation. Urea was top-dressed in three equal splits at 15 DAT, 30 DAT and 50 DAT. Three hand weeding and one spraying were applied to control weeds and attack of insect-pest respectively. Irrigation water was applied through plastic pipe from the source and a volumetric method was used for measuring irrigation water. Perforated PVC pipe was installed up to a depth of 15, 20, and $50 \mathrm{~cm}$ below ground surface for monitoring perched water table depth at field level. Field water depth, rainfall and evaporation were recorded during the season. Initial soil moisture content of each plot was measured before starting each irrigation. Rice yield was assessed on the basis of 5 square meter area. Harvested paddy was threshed, cleaned and weighed to determine yield. Finally, grain yield was adjusted to $14 \%$ moisture content. Quantitative information related to yield and all the yield contributing characters like, panicle per square meter, filled and unfilled grain per panicle and water productivity were analyzed to obtain the effect of AWD on rice yield.

\section{RESULTS AND DISCUSSION}

Yield and yield contributing characters are shown in Table 1. The numbers of spikelets per panicle in AWD treatments were lower compared to treatment $T_{1}$ and it was the highest in $\mathrm{T}_{2}$ during 2011-12. The water treatments also affected filled grains. In 2010-11, the maximum 
number of filled grains per panicle was 103 in $T_{1}$ and the number consistently decreased in $\mathrm{T}_{2}$ (102), $\mathrm{T}_{3}(90)$ and $\mathrm{T}_{4}(81)$. In 2011-12, the maximum number of filled grains per panicle was 146 in $\mathrm{T}_{2}$ followed by $\mathrm{T}_{1}(140), \mathrm{T}_{3}(112)$ and $\mathrm{T}_{4}$ (132), respectively. The number of panicle $/ \mathrm{m}^{2}$ was highest $\left(325 / \mathrm{m}^{2}\right)$ in $\mathrm{T}_{1}$ during 2010-11 and in $\mathrm{T}_{2}\left(331 / \mathrm{m}^{2}\right)$ during 2011-12. The AWD irrigation treatments influenced grain yield for both the seasons. The highest grain yield (5.9-6.2 ton/ha) was obtained in $\mathrm{T}_{2}$ and the lowest (4.6-4.7 ton/ha) was in $\mathrm{T}_{4}$ for both the seasons. However, grain yield in $\mathrm{T}_{1}$ (5.7-6.0 ton/ha) was very close to $\mathrm{T}_{2}$ (5.9 and 6.2 ton/ha) during 2010-11 and 2011-12. In this study, there is no significant difference between treatments $T_{1}$ and $T_{2}$ considering yield (Table 1). But variation observed among treatments $\mathrm{T}_{1}, \mathrm{~T}_{3}$ and $\mathrm{T}_{4}$ at $5 \%$ level in both the seasons. From the experiment it was found that higher water stresses resulted in greater yield losses.

Table 1 Yield and yield contributing characters of BRRI dhan28 under different irrigation treatments during 2010-11 and 2011-12

\begin{tabular}{lcccc}
\hline Treat. & Panicle $/ \mathrm{m}^{2}$ & $\begin{array}{c}\text { No. of spikelets } \\
\text { panicle }{ }^{-1}\end{array}$ & $\begin{array}{c}\text { No. of filled } \\
\text { grain panicle }{ }^{-1}\end{array}$ & $\begin{array}{c}\text { Grain yield } \\
(\mathrm{t} / \mathrm{ha})\end{array}$ \\
\hline & \multicolumn{2}{c}{ Year 2010-11 $^{2}$} & & \\
\hline $\mathrm{T}_{1}$ & 325 & 130 & 103 & 5.7 \\
$\mathrm{~T}_{2}$ & 319 & 120 & 102 & 5.9 \\
$\mathrm{~T}_{3}$ & 317 & 122 & 90 & 5.4 \\
$\mathrm{~T}_{4}$ & 302 & 118 & 81 & 4.6 \\
$\mathrm{LSD}_{0.05}$ & 12 & 7 & 5 & 0.3 \\
$\mathrm{CV}(\%)$ & 2 & 3 & 2.7 & 3 \\
\hline & & Year 2011-12 & & \\
\hline $\mathrm{T}_{1}$ & 325 & 162 & 140 & 6.0 \\
$\mathrm{~T}_{2}$ & 331 & 165 & 146 & 5.2 \\
$\mathrm{~T}_{3}$ & 305 & 146 & 112 & 4.6 \\
$\mathrm{~T}_{4}$ & 290 & 125 & 132 & 0.6 \\
$\mathrm{LSD}_{0.05}$ & 10 & 8 & 18 & 4.1 \\
$\mathrm{CV}(\%)$ & 1.6 & 3 & 4.4 & \\
\hline
\end{tabular}

\section{Total Water Use and Water Productivity}

Rainfall during the growing period of rice was $313 \mathrm{~mm}$ and $215 \mathrm{~mm}$ (Table 2) which created congenial environment for rice production in Boro season and reduce irrigation requirement. Total water inputs (rainfall and irrigation) ranged from 1013-645 $\mathrm{mm}$ in 201011 and 1100-680 mm in 2011-12 (Table 2). Maximum irrigation water needed (598 $\mathrm{mm}$ ) to maintain continuous standing water, but in AWD treatments it was $392 \mathrm{~mm}$ (applying irrigation after $15 \mathrm{~cm}$ depletion of water level), $305 \mathrm{~mm}$ (applying irrigation after $20 \mathrm{~cm}$ depletion of water level) and $230 \mathrm{~mm}$ (applying irrigation after $50 \mathrm{~cm}$ depletion of water level) during 2010-11. In 2011-12 maximum irrigation water needed was $770 \mathrm{~mm}$ in $\mathrm{T}_{1}$ followed by $550 \mathrm{~mm}$ in $\mathrm{T}_{2}, 390 \mathrm{~mm}$ in $\mathrm{T}_{3}$ and $350 \mathrm{~mm}$ in $\mathrm{T}_{4}$. It observed that total water use varied significantly at $1.9 \%$ and $1.3 \%$ level in 2010-11 and 2011-12. Water productivity is the most important criterion to rationalize AWD practice. The water productivity varied among irrigation treatments and it ranged from 5.4 to $7.6 \mathrm{~kg} / \mathrm{ha}-\mathrm{mm}$ depending on season and water treatments. The highest water productivity was 7.3 and $7.6 \mathrm{~kg} / \mathrm{ha}-\mathrm{mm}$ in $\mathrm{T}_{3}$ and the lowest (5.4 and $5.6 \mathrm{~kg} /$ ha-mm) in $\mathrm{T}_{1}$ during 2010-11 and 2011-12, respectively. The second highest water productivity was $7.1 \mathrm{~kg} / \mathrm{ha}-\mathrm{mm}$ in $\mathrm{T}_{2}$ which was very close to the highest one in $\mathrm{T}_{3}$. The AWD treatment $\mathrm{T}_{2}$ (applying irrigation after $15 \mathrm{~cm}$ depletion of water below soil surface) saved $20 \%$ irrigation water and gave higher grain yield. There is an indication that the variation of water productivity only $\mathrm{T}_{1}$ with others three treatments (Significant at $5 \%$ 
level), but no significance difference among treatments $T_{2}, T_{3}$ and $T_{4}$ in both seasons. Moreover, AWD treatments $\mathrm{T}_{3}$ and $\mathrm{T}_{4}$ saved irrigation water but gave lower grain yield consistently.

Table 2 Yield and water applied in rice field at BRRI farm Gazipur during Boro season 2010-11 and 2011-12

\begin{tabular}{|c|c|c|c|c|c|c|c|c|}
\hline Treat. & $\begin{array}{l}\text { Land } \\
\text { prep. } \\
\text { water } \\
(\mathrm{mm})\end{array}$ & $\begin{array}{l}\text { Irrigation } \\
\text { water } \\
(\mathrm{mm})\end{array}$ & $\begin{array}{l}\text { Rain } \\
\text { fall } \\
(\mathrm{mm})\end{array}$ & $\begin{array}{l}\text { Total } \\
\text { water } \\
(\mathrm{mm})\end{array}$ & $\begin{array}{l}\text { Yield } \\
(\mathrm{kg} / \mathrm{ha})\end{array}$ & $\begin{array}{l}\% \quad \text { of } \\
\text { water } \\
\text { saved } \\
\text { over } T_{1}\end{array}$ & $\begin{array}{l}\text { Yield } \\
\text { decreased } \\
\text { /increased } \\
\text { over } \mathrm{T}_{1} \\
(\mathrm{~kg} / \mathrm{ha})\end{array}$ & $\begin{array}{l}\text { Water } \\
\text { Productivity } \\
(\mathrm{Kg} / \text { ha- } \\
\mathrm{mm})\end{array}$ \\
\hline \multicolumn{9}{|c|}{ Year 2010-11 } \\
\hline $\mathrm{T}_{1}$ & 102 & 598 & 313 & 1013 & 5700 & - & - & 5.6 \\
\hline $\mathrm{T}_{2}$ & 102 & 392 & 313 & 807 & 5900 & 20 & 200 & 7.1 \\
\hline $\mathrm{T}_{3}$ & 102 & 305 & 313 & 720 & 5400 & 29 & -300 & 7.3 \\
\hline $\mathrm{T}_{4}$ & 102 & 230 & 313 & 645 & 4600 & 36 & -1100 & 7.1 \\
\hline $\mathrm{LSD}_{0.05}$ & & & & 31 & & & & 0.6 \\
\hline CV $(\%)$ & & & & 1.9 & & & & 4.5 \\
\hline \multicolumn{9}{|c|}{ Year 2011-12 } \\
\hline $\mathrm{T}_{1}$ & 115 & 770 & 215 & 1100 & 6000 & - & - & 5.4 \\
\hline $\mathrm{T}_{2}$ & 115 & 550 & 215 & 880 & 6200 & 20 & 200 & 7.1 \\
\hline $\mathrm{T}_{3}$ & 115 & 390 & 215 & 720 & 5500 & 25 & -500 & 7.6 \\
\hline $\mathrm{T}_{4}$ & 115 & 350 & 215 & 680 & 4700 & 38 & -1300 & 6.9 \\
\hline $\mathrm{LSD}_{0.05}$ & & & & 22 & & & & 0.6 \\
\hline CV (\%) & & & & 1.3 & & & & 4.7 \\
\hline
\end{tabular}

\section{Economic Analysis}

Given the same input cost of fertilizer, insecticide, weeding and labor cost for all treatments, $\mathrm{T}_{1}$ incurred more cost in irrigation than other three treatments. Compared to $\mathrm{T}_{1}, \mathrm{AWD}$ in $\mathrm{T}_{2}$, $\mathrm{T}_{3}$ and $\mathrm{T}_{4}$ saved irrigation water by 206, 293 and $368 \mathrm{~mm}$ in 2010-11 and 220, 380 and $420 \mathrm{~mm}$ in 2011-12, respectively. $T_{2}$ gave higher economic benefit than $T_{1}$ in both the years (Tk. 5561 in 2010 -11 and Tk. 6262 in 2011-12). However, because of decreased yield in $T_{3}$ and $T_{4}$, these treatments were not economically profitable over $\mathrm{T}_{1}$.

\section{CONCLUSIONS}

In practicing AWD method, there is a controversy about the depth of water level below soil surface between $15 \mathrm{~cm}$ and $20 \mathrm{~cm}$ for getting maximum benefit. To solve that controversy the present study was carried out and refinement of AWD method revealed that application of irrigation $(5-7 \mathrm{~cm})$ is more economical for Boro rice cultivation when water remain $15 \mathrm{~cm}$ below the soil surface. It saved 20-30 \% irrigation water without hampering rice yield, even sometimes increased yield by 0.2-0.5 t/ha. The additional benefit of AWD method was Tk.5476/ha over continuous standing water practice. It is recommended that in AWD system irrigation should be applied when water level is $15 \mathrm{~cm}$ below the soil surface. Irrigation application below this level will decrease yield, significantly. So, farmers can irrigate their rice fields when water is $15 \mathrm{~cm}$ below the soil surface for clay loam soil for getting maximum benefit.

\section{REFERENCES}

BBS (Bangladesh Bureau of Statistics). 2009. 2008 Year Book of Agricultural Statistics of Bangladesh. Ministry of Planning, Bangladesh. 
Bouman, B A M, R Lampayan, T P Tuong. 2007. Water Management in Irrigated Rice: Coping with Water Scarcity. International Rice Research Institute. Los Banos, Laguna: IRRI.

Hoekstra, A Y. 2008. Water for Food (51-52). The water footprint of food. Twente Water Centre, University of Twente, the Netherlands.

IRRI (International Rice Research Institute) (2010) accessed 15.11.2010 http://www.knowledgebank.irri.org/watermanagement/

Lampayan, R M, F G Palis, R B Flor, B A M Bouman, E D Quicho, J L De Dios, A Espiritu, E B Sibayan, V R Vicmudo, A T Lactaoen, and J B Soriano. 2009. Adoption and Dissemination of "Safe Alternate Wetting and Drying" in Pump Irrigated Rice Areas in the Philippines. In: 60th International Executive Council Meeting of the International Commission on Irrigation and Drainage (ICID), 5th Regional Conference, 6-11 December 2009, New Delhi, India.

Li, Y H and R Barker. 2004. Increasing water productivity for rice field irrigation in China. Rice field water Environ. 2:187-193.

MoA (Ministry of Agriculture). 2010. Report on National Agriculture Policy, Dhaka.

Pingali, P L, M Hossain, and R V Gerpacio. 1997. Asian rice market: demand and supply prospects. In: Asian rice bowls: the returning crisis? CAB International, Wallingford, UK and International Rice Research Institute, Los Banos, The Philippines: 126-144.

Postal, S. 1997. Last oasis: facing water scarcity. New York (USA): Norton and Company: 239.

Sharma, P K. 1989. Effect of periodic moisture stress on water use efficiency in wet land rice. Oryza. 26:252-257.

Tuong, T P and B A M Bouman. 2003. Rice production in water scarce environments. In: Kijne JW, Barker R, Molden D, editors. Water productivity in agriculture: Limits and opportunities for improvements. Wallingford (UK): CABI publishing: 53-67. 